\title{
A TERMÉKINFORMÁCIÓ FOGYASZTÓI MAGATARTÁST BEFOLYÁSOLÓ HATÁSA AZ ÉLELMISZERVÁSÁRLÁS SORÁN
}

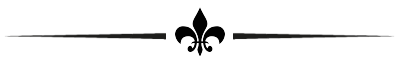

\section{THE EFFECT OF PRODUCT INFORMATION ON THE CONSUMER BEHAVIOUR IN THE COURSE OF FOOD PURCHASE} \\ Soós, Gabriella

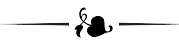 \\ Eszterházy Károly Egyetem, Gazdaság- és Társadalomtudományi Kar, Gazdaságtudományi Intézet, Vállalkozásgazdaságtan Tanszék \\ (Eszterhazy Karoly University, Faculty of Economic and Social Sciences, Institut of Economic Sciences, Department of Business Economics) \\ H-330o Eger, Eszterházy tér 1. \\ soos.gabriella@uni-eszterhazy.hu
}

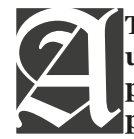

This study investigates the course of the consumer's information progression in order to underlie further quantitative and qualitative researches. This survey reviews the whole process of the information progression through which the consumer can decide which product to choose. The optimal consumption structure is configured by different principles and effects, and on the other hand every consumer is influenced by a diversity of information during the decision making process and the usage as well. The process of how individuals elaborate this information depends on numerous factors. The demographic and personality factors, qualification and profession, extant knowledge, the motivation for looking for information are very important as well as the evaluation of data. The cognitive, conative and emotive attitudes play an important role in the different stages of the information processes. The diverse information sources have a different effect on the consumer, too. The effectiveness of the information transfer is influenced by the consciousness of the consumer and how voluntarily they want to optimize their decision. In this process the extent to which they are concerned (for example a disease or prevention) plays a remarkable role. An important function of the stakeholders is to support the consumer's decision with incomplex, laconic and authentic information. Without this the intended communication may generate a contradictory effect, however too much information may lead to rejection.

KULCSSZAVAK: élelmiszermarketing, fogyasztói magatartás, információ, csomagolás, termékcímke

JELKóD: M31, P36
KEYWORDS: food marketing, consumer behaviour, information, packaging, product label

\section{BEVEZETÉS - INTRODUCTION}

Az élelmiszeriparban is egyre inkább érzékelhető trend, hogy számos forrásból érik a fogyasztót a döntésére ható információk. A média által sugárzott marketing akciók célja a befolyásolás. Emellett fontos szerepet játszanak a kormányzati és tudományos ismeretterjesztő eszközök, melyek a vásárlókat a tudatos vásár- lásra és az egészséges és számukra optimális fogyasztási szerkezet kialakítására ösztönzik. Ebben fontos szerepet játszanak a terméken feltüntetett információk. A termékcímke kialakítása így együttesen szolgálja a fogyasztó tájékoztatását és hordoz marketing célokat. Fontos megjegyezni, hogy az élelmiszeripari szereplők által tervezett információátadás és a fogyasztó által érzékelt információbefogadás és értékelés 
között jelentős differencia húzódhat meg, ezért fontos megérteni az egyének információkeresési, -feldolgozási és -értékelési folyamatát annak érdekében, hogy a fogyasztó a számára legoptimálisabb döntést hozhassa meg. Jelen kutatás ezen tényezők feltárására és összefoglalására vállalkozik.

\section{ANYAg ÉS MÓDSZER - MATERIAL AND METHOD}

Jelen tanulmány fó célja a fogyasztók információkezelésére ható tényezők feltérképezése. A szakirodalmi kutatás kiterjedt a hazai és külföldi tanulmányok elérésére és feldolgozására, melyek lehetővé teszik a folyamat modelljének összeállítását oly módon, hogy az további kvalitatív és kvantitatív kutatások kiindulópontja lehessen. A kutatás elsősorban akadémiai adatbázisok segítségével történt, ezek közül a leggyakrabban alkalmazottak a Cambrige Journal, a Web of Science, az EBSCO, a JStore, a Science Direct, a Scopus és a Springer Link. A folyóiratcikkek mellett fontos kiindulópontot jelentettek a hazai és külföldi szakkönyvek, melyek elsősorban az élelmiszermarketing tematikájára fókuszáltak.

A feltáró kutatás során a felhasznált szakkönyvek és folyóiratcikkek azon tényezői kerültek kiemelésre, melyek hatással vannak a fogyasztók információfeldolgozási folyamatára. Az elméleti összefoglalást követően röviden utalunk a fogyasztók információhasználatát vizsgáló főbb kutatási eredményekre.

\section{AZ ÉLELMISZER-CSOMAGOLÁS MARKETING FUNKCIÓI - The Marketing Function of The FoOD PACKAgING}

Az élelmiszerek az átlagos termékekhez (pl. ruházat, tartós fogyasztási cikkek) képest fontosabb szerepet töltenek be a fogyasztási szerkezetben, hiszen hozzájárulnak a létfenntartáshoz és az egészségmegőrzéshez. Vásárlásuk jórészt napi rendszerességgel, rutinszerüen történik, de vannak olyan - különlegesebb igényt kielégítő - élelmiszerek, amelyeket ritkábban, hosz- szabb megfontolás után választunk.

$\mathrm{Az}$ élelmiszerek közvetlenül (fogyasztást követően azonnal) és közvetve (rendszeresen) is hatással vannak az egészségi állapotunkra. A korszerü fogyasztási szerkezet kialakítása rendkívül fontos az egészségmegőrzés szempontjából. A fogyasztók egyre inkább felismerik, hogy fontos odafigyelniük a megfelelő termékek kiválasztására, hiszen ezzel saját életkörülményeiket alakíthatják.

A megfelelő élelmiszerek biztosítása ugyanakkor nem csak a fogyasztók feladata. Az élelmiszergyártást és forgalmazást felügyelő hatóságok szabályozzák azon élelmiszerek körét és követelményeit, amelyek a fogyasztóhoz kerülhetnek. A magyar szabályozás az Európai Uniós jogrendszer szerint készült.

A termékek címkézését, az azon szereplő informatív és fogyasztói magatartást befolyásoló elemek megjelenését két alapvető faktor befolyásolja: a címkézésre vonatkozó jogszabályi, hatósági előírások, valamint a fogyasztóra gyakorolt, vagy gyakorolni kívánt hatás.

\subsection{A címkézés törvényi előírásairól néhány szóban - About the Product Label by Course of Law in Few Words}

A törvényi szabályozás mai állapotának létrejötte hosszú folyamat, egészen az 1800-as évek végéig nyúlik vissza. Jelen cikkben röviden kerül összefoglalásra a területet jelenleg meghatározó fóbb szabályzók területe.

A 2000. január 12-én megjelent Európai Uniós Fehér Könyv tartalmazza a fogyasztói információkra vonatkozó részletes alapelveket (White Paper On Food Safety, 2000.). Az Európai Parlament és a Tanács 2000/13/EK irányelve fektette le az élelmiszerjelölés és -reklámozás alapelveit. Ezt követően az Európai Parlament és a Tanács 178/2002/EK rendelete meghatározta az élelmiszer fogalmát, szabályozta az élelmiszerjog általános elveit és követelményeit.

Az 1169/2011/EU rendelet célja a fogyasztóvédelem szigorítása és a minőség szabályozása. A rendelet előírja a termék- (2000/13/ EK Európai Parlamenti és Tanácsi irányelv) és tápértékjelölés (90/496/EGK tanácsi irányelv) naprakésszé tételét. A rendelet definiál olyan fogalmakat, amelyek a későbbi jelölésszabá- 
lyozásokhoz szükségesek, például az összetevő, címke, jelölés vagy látómező. A rendelet 4. fejezet 1. szakasz 9. cikkének (1) bekezdése meghatározza az élelmiszereken kötelezően feltüntetendő adatok körét.

Hazánk első élelmiszertörvénye 1895-ben jelent meg, elsősorban az élelmiszerhamisítás tilalmáról szól (1895. évi XLVI. törvénycikk a mezőgazdasági termények, termékek és cikkek hamisításának tilalmazásáról).

Már az 1995. évi élelmiszertörvény (1995. évi XC. törvény az élelmiszerekrôl és végrehajtási rendelete: 1/1996. (I. 9.) FM-NM-IKM rendelet és módosítása a 2001. évi LIV. törvény) tartalmazott szabályzókat az élelmiszerek országok közötti szabad áramlására vonatkozóan, de az egységes európai joghoz való alkalmazkodást a 2003. évi törvény (2003. évi LXXXII. törvény az élelmiszerekről) teremtette meg. A Magyar Élelmiszerkönyv első kiadása 1995-ben jelent meg, ezt követte a 2001. évi második, módosított kiadás. A Magyar Élelmiszerkönyv (Codex Alimentarius Hungaricus) jelenleg hatályos, 2013. évi változata a Földművelésügyi Minisztérium oldalán hozzáférhető (Magyar Élelmiszerkönyv, 2013). 19/2004-es rendelet (19/2004. (II. 26.) FVM-ESzCsM-GKM együttes rendelet az élelmiszerek jelöléséról) fogalom-meghatározásokkal és EU-normákra utalással egészíti ki az élelmiszertörvény rendelkezéseit az élelmiszerek jelölésére vonatkozóan. A 36/2014. rendelet (36/2014. (XII. 17.) FM rendelet az élelmiszerekkel kapcsolatos tájékoztatásról) tartalmazza az élelmiszerekkel kapcsolatos tájékoztatás szabályozását, különös tekintettel a nem előrecsomagolt termékekre, valamint a tételazonosító jelölésére vonatkozóan. A 13/2008. számú rendelet (13/2008. (VIII. 8.) NFGM-FVM együttes rendelet az előrecsomagolt termékek névleges mennyiségére vonatkozó szabályok megállapításáról és azok ellenőrzési módszereiről) az előrecsomagolt termékek névleges mennyiségének meghatározására és jelölésére vonatkozó szabályokat foglalja össze. A 74/2012. számú rendelet (74/2012. (VII. 25.) VM rendelet egyes önkéntes megkülönböztető megjelölések élelmiszereken történő használatáról) az önkéntes tájékoztatást szabályozza. A jogszabály a megfelelő EK-rendeletre való utalással határozza meg a szükséges definíciókat, meghatározza a magyar származásra, a kézzel készítés jelölésére, valamint a minőségi fokozatra való utalás fontosabb szabályait.

Fenti jogszabályok tehát alapvetően meghatározzák a termékeken elhelyezhető információk kereteit, melyekhez a címke tervezésekor alkalmazkodni kell. A törvényi előírásokon túl a gyártók és kereskedók arra törekszenek, hogy a fogyasztókból a vásárlási döntés számukra legkedvezőbb magatartását váltsák ki. Ehhez tervezik a csomagolást és a terméken szereplő információkat. A továbbiakban a csomagolás marketing funkcióit vesszük sorra.

\subsection{A csomagolás és a termék- információk marketing szerepe - The Marketing Role of the Packaging and the Product Information}

A csomagolás azon túl, hogy védi a terméket a környezet hatásaitól (adott esetben a környezetet a termék hatásaitól, pl. ecet), fontos marketing funkciókat hordoz. A fogyasztó elsőként a csomagolással találkozik, ha ez számára nem vonzó, további információszerzés nélkül eláll a vásárlástól. A jó csomagolás utal a termék piacon elfoglalt helyére (pozícionál), egyéniséget sugall, termékelőnyöket hangsúlyoz. „A csomagolás egysége megidézi a termékkategóriát, a márkát és már az első benyomás alapján kapcsolatot teremt a fogyasztóval." (LEHOTA, 2001, 204. o.).

A formadesign mellett fontos szerepe van a színhatásnak, minden színnek megvan a maga üzenete. Fontos, hogy az élelmiszeren elhelyezett címke illeszkedjen a csomagolás által sugallt imázs-elemekhez. Ugyanakkor meg kell felelnie a tájékoztatással kapcsolatos alapelveknek, a fogyasztó számára pontos és lényeges információt kell szolgáltatni a döntéshez. Ez nem könnyü feladat, hiszen a kötelezően megjelenítendő és lehetséges információk köre széles, ugyanakkor a kisméretü termékek felülete gyakran nem teszi lehetővé az alapos és egyben olvasható méretü tájékoztatást.

Az élelmiszeren szereplő információk nem csupán az élelmiszerbiztonsági szempontok miatt fontosak, hanem lényeges szerepük van a fogyasztó döntésében. A jól informált fogyasztó megalapozottabb döntést tud hozni a vásárlás során, így a fogyasztás is nagyobb eséllyel vált 
ki számára elégedettséget, ennek köszönhetően nagyobb lehet az újravásárlások aránya. A megfelelő információval rendelkező vásárló ki tudja választani az egészségi állapotának, elvárásainak, diétájának, elveinek legmegfelelőbb élelmiszert, így meg tud küzdeni betegségével, vagy meg tudja előzni ezek kialakulását.

Lehota szerint az élelmiszer-jelölés marketing funkciói az alábbiak:

- racionális információkat közvetít, megkülönböztet, minőségre utal,

- figyelmet kelt,

- esztétikai élményt nyújt,

- bizalmat kelt, vásárlási motivációt erősít,

- nevel, tanít (LEHOTA, 2001, 210. o.).

A fenti hatásokat az írás, színek, formák, grafikai megoldások, ezek elhelyezkedése és méretarányai segítségével lehet kiváltani.

A fogyasztók fontos információként kezelik a csomagoláson megjelenő adatokat, de ez önmagában nem elegendő a tudatos döntés meghozatalához. „A csomagoláson található állítások gyorsan és hatékonyan segítik az értelmezhetőséget és általában támogatják a vásárlási döntés meghozatalát. Ha terméken túl sok és bonyolult információ szerepel, akkor a vevők könnyebben utasítják el a vásárlást, ellenkező esetben viszont ösztöni őket.” (SZAKÁLY, 2011, 76-77. o.). Tehát a marketing funkciók csak úgy válhatnak teljessé, ha a terméken elhelyezett információk rövid, tömör, egy átlagos fogyasztó által értelmezhető formában tartalmazzák a döntéshez szükséges alapvető információkat, míg az ezt kiegészítő bővebb, ismeretterjesztő tudásanyag más forráson keresztül jut el hozzájuk.

\section{AZ INFORMÁCIÓK FOGYASZTÓI DÖNTÉST BEFOLYÁSOLÓ SZEREPE \\ - THE InFLUENTIAL IMPACT OF THE INFORMATION IN THE CONSUMER DECISION}

Az információk keresésének és elfogadásának folyamatát alapvető demográfiai és földrajzi tényezők befolyásolják. „A tudatosság nagyobb a nőknél, az életmódbetegségekben szenvedőknél, valamint az idősebb fogyasztóknál.” Az európai fogyasztóknál alacsonyabb a címkék elolvasásának aránya a vásárlás előtt, mint az indiai és kínai vásárlók esetében (SZAKÁLY, 2011, 76. o.).

Lehota 2006-os cikkében az élelmiszerek kockázatvizsgálata kapcsán fogalmazza meg a fogyasztóknak az információkezeléssel kapcsolatos hiányosságait. „Az élelmiszerfogyasztó vásárlási és fogyasztói döntéseit tökéletlen információellátottság mellett hozza meg. A tökéletlen információellátottság fő jellemzői az alábbiak:

- A termékekkel kapcsolatos - a fogyasztói döntésekhez szükséges - összes információ nem áll rendelkezésre

- A fogyasztó nem képes az összes rendelkezésre álló információt feldolgozni, döntéseiben integrálni

- A fogyasztó és a vásárlási döntések egy része a jövőbeni változásokra és feltételezésekre épül, ezért azok nem determinisztikus, hanem csak valószínűségi információk." (LEHOTA, 2006).

Fontos továbbá, hogy a fogyasztó végig akarjon menni az információfeldolgozás teljes folyamatán (észlelés, figyelem, megértés, elfogadás, megjegyzés), méghozzá racionális úton, amíg eljut a döntésig (GRUNERT, 2002, 282283. o.).

Grunert modellje összefoglalja az információk fogyasztói feldolgozásának a folyamatát. Ez alapján az érdekeltség, a tudás, a demográfiai adatok és a címke formátuma befolyásolja a feldolgozás folyamatát, amely a kereséssel kezdődik, az információknak való kitettséget szerencsés esetben az észlelés követi. A következő fázis a kedvelés, a megértés és a következtetés szakasza. A megértés nem csak tudatos folyamat lehet, hanem tudat alatt is végbemehet. A folyamat befejezéseként megtörténik a használat, amely lehet egyszeri, vagy tartós, direkt vagy indirekt (GRUNERT-WILLS, 2007).

Szakály továbbfejlesztette Van Trijp 2009es modelljét oly módon, hogy az információfeldolgozás fázisait az attitüdre gyakorolt hatás alapján is rendezte. Ennek megfelelően az érdeklődés és figyelem szakaszban a kognitív, az észlelés és megértés során az affektív, míg a használat során a konatív (cselekvésre ható, cselekvés alapú) attitűd érintett (SZAKÁLY, 2011, 196. o.). Az élelmiszerekkel kapcsolatos 
ismeretformálás tehát a fogyasztók kognitív attitűdjét alakítja elsősorban. Az affektív attitüdre jelentős mértékben hatnak az alkalmazott marketing elemek (színhatás, jelmondatok, stb.). A vásárlást követő használat már a fogyasztó konatív attitüdjével van összefüggésben, a folyamat értékelése hat a további vásárlási folyamatra. Pozitív visszacsatolás esetén nagyobb valószínúséggel történhet újravásárlás és alakulhat ki hosszú távon a márkahüség.

A fogyasztó élelmiszerekkel, biztonsággal, az összetevőkkel kapcsolatos tudása alapvetó az információ észlelése és értelmezése során. Minél inkább tudatában van az élelmiszerválasztással és -fogyasztással járó kockázatoknak, annál inkább hajlandó több időt szánni a döntésre, illetve az ahhoz kapcsolódó információkeresésre. Ugyanakkor a több információ nem jelenti feltétlenül a jobban informáltságot, hiszen azt befolyásolja az információfeldolgozás folyamata, valamint, hogy hordoz-e olyan adatot, amely a célközönség számára fontos. Ugyanakkor az is lényeges tényező, hogy ha a fogyasztót túl sok információ éri, akkor inkább figyelmen kívül hagyja (VERBEKE, 2008, 283284. o.).

A tudásszint és az információfeldolgozás folyamata mellett fontos szerepet játszanak a hiedelmek is. Egy Belgiumban, funkcionális élelmiszerekkel kapcsolatban végzett kutatás szerint az egészséges hatásban való hit a legfontosabb meghatározó a funkcionális élelmiszerek elfogadásában (VERBEKE, 2005). Ugyanakkor kérdés, hogy a fogyasztók mennyire tartják hitelesnek a terméken, termékcímkén, a gyártó vagy forgalmazó által elhelyezett, egészséges hatásra utaló állítást.

Egészséges hatásra való utalás az, amelyik kijelenti vagy sugallja, hogy az élelmiszer a hagyományosnak tekinthetőtől eltérő tulajdonságokkal rendelkezik. Élettani hatásra vonatkozó állítást csak akkor lehet elhelyezni a terméken, ha a hatás bizonyított. A tudományos háttér igazolása a gyártó, forgalmazó vállalat felelőssége. Nem alkalmazhatók olyan jelölések, amelyek azt sugallják, hogy az élelmiszer fogyasztásának mellőzése hatással lehet az egészségre, ha a súlycsökkenés mértékére és ütemére utalnak, vagy ha egyes orvosok, vagy egyéb egészségügyi szakemberek, vagy nem nemzeti szinten elfogadott orvosi, táplálkozástudomá- nyi és dietetikus szakemberek egyesületeire hivatkoznak.

A hiedelmek, a tudás és a felelősség összefüggését Szakály is elemzi könyvében. Vizsgálatában a fogyasztók bizonytalanságának az a hiedelem az oka, hogy külső tényezők is befolyásolják az egészség alakulását. „A hazai vásárlók részben elhárítják saját felelősségüket, felértékelik az irányíthatatlan tényezőket, hinni akarnak a sorsszerüségben, az „úgyis mindegy" állapotban. Az eredmények alapján összefoglalva megállapítható, hogy a hazai lakosság mintegy 70-75 \%-ának vannak erős és egyirányú hiedelmei a táplálkozás és az egészség kapcsolatáról." (SZAKÁLY, 2011, 108-109. o.).

Az objektív minőség ugyanakkor nem értelmezhető egyértelműen a fogyasztó számára érvényesülő pozitív hatásként, mert ez nem egyezik meg a fogyasztó által érzékelt biztonsággal. Szakály szerint ugyanis egyfajta kommunikációs rés húzódik meg a tudományos tudás és a marketing információk megközelítése között, melyet az „ún. Kiss-törvénnyel lehet áthidalni, amely feloldja a nyilvánvaló érdekellentétet a tudományos érvek és a fogyasztói értelmezés között... A Kiss-törvény szerint a marketing fogyasztóbarát stílusban és emocionális érvekkel igyekszik meggyőzni a vevőket az egészségvédő élelmiszerek vásárlásának helyességéről, ezért jelenik meg a „Legyél könnyed és emocionális!" érvrendszer a vállalati kommunikációban” (SZAKÁLY, 2011, 18. o.).

Verbeke 2007-ben megjelent cikkében megemlíti az ún. „érzékelés szűrő” jelenlétét, mely „A tudományos realitás és az emberi érzékelés között a tükör" szerepét tölti be és felelős azért, hogy létrehozza a „téves észleleteket”. Az érzékelés szűrő hatását sok tényező befolyásolja, leginkább a kommunikáció, a szituációs tényezők és az egyéni sajátosságok. Az észlelést meghatározza a fogyasztó érzelmi stabilitásának szintje is. A negatív információk az alacsonyabb érzelmi stabilitásúakat erősebben befolyásolják.

Verbeke rámutatott arra, hogy a kommunikáció kapcsán meghatározó a vizuális elemek és a márka hatása. Egy erôs márka esetén a biztonságra vonatkozó negatív információk hamarabb vesztették el fogyasztást befolyásoló hatásukat, mint egy márka nélküli termék esetében, az erős vizuális hatás egy élelmiszerbiztonsági 
probléma esetén markáns fogyasztásmegtagadást váltott ki. Funkcionális termékek esetén az elfogadást alapvetően az egészségügyi előnyökbe vetett hit határozza meg, függetlenül a társadalmi és a demográfiai jellemzóktől. Verbeke felhívja a figyelmet, hogy a kommunikáció akkor lehet hatásos, ha a fogyasztó betekintést kap a feldolgozás folyamatába, tudatosíthatja az alapanyagok tulajdonságait (VERBEKE, 2007).

Az információszerzés módja is meghatározza annak tudatosulását és megjegyzését. Az információszerzés módja egy egyszerü megközelítés szerint piaci rétegenként különbözik. Eszerint a piac 3 alapvető rétegre különíthető el: felső-, közép- és alsó piacra. A felső- és középpiacot elsősorban márkavásárlók, míg az alsópiacot inkább árvásárlók alkotják. A felsőpiac erősen márkázott termékei esetén a tömegkommunikációs eszközök nem jöhetnek szóba, a szereplők nem befogadók a tömegmédiát illetően, így itt inkább a szájreklám, a bennfentes információ, a réteglapok jelentik a fő információforrást, ahol a hirdetéseket diszkrét utalások jellemzik. A csábítás az üzenetátadás fő módszere. A középpiac „az idillt adja vissza, a ,jobb lesz” illúzióját támogatja” Az elérhető vágyakra fókuszál az információátadás. Ezt a réteget elsősorban tömegkommunikációs eszközök segítségével lehet elérni. Az alsópiaci kommunikáció az ár közlésére fókuszál, a funkcionális jellemzők lehetnek még fontosak, valamint élénk színek, harsány feliratok jellemzik (TÖRŐCSIK, 2007, 104-108. o.).

Fontos azon források azonosítása, ahol a fogyasztók többnyire az információikat szerzik. Szakálynak a funkcionális élelmiszerek fogyasztóira vonatkozó kutatása szerint a fó források gyakoriságuk szerinti sorrendben a következők: közvetlen környezet (pl. családtagok, barátok), élelmiszercímke, reklámok, magazinok, televízió-műsorok, kereskedők, internet és egyéb források. „A fogyasztóvédelem, az ellenőrző hatóság, valamint a táplálkozás-politikai szervezetek hiteles információkat közölnek, de a fogyasztók ritkán tájékozódnak ilyen forrásokból.” Attól, hogy egy forrás hiteles, még nem biztos, hogy a fogyasztó is így értékeli. A kutatás szerint a leghitelesebbnek az alábbi adatforrásokat találták a válaszadók (gyakorisági sorrendben): élelmiszercímkék, orvosok, családtagok és barátok, fogyasztóvédelem. A reklámokkal szembeni bizalmatlanság a végzettséggel együtt nő. A megkérdezettek az élelmiszercímkék után az orvosokat jelölték meg számukra leghitelesebb forrásként, majd a családtagok, barátok következnek, végül a fogyasztóvédelem. „Az élelmiszer-kereskedő jellemzően sehol sem tartozik a megbízható és kedvelt kommunikációs csatornák közé." (SZAKÁLY, 2011, 135-137. o.). A szakemberek számára nehéz ellentmondás, hogy a fogyasztóvédelem információiban megbíznak a vásárlók, azonban ezt a forrást kevésbé használják információszerzésre, ugyanakkor a tömegmédia közlései gyakran érik el a fogyasztót, ezekben viszont nem bíznak meg. A fogyasztó meggyőzésére hitelesen használható eszköz tehát a termékcímke, valamint az orvosok, dietetikusok, táplálkozási tanácsadók bevonása a marketingkommunikációba.

Az információkeresés iránya mellett fontos, hogy a fogyasztó mennyire szeretne információhoz jutni a vásárlási döntéséhez. Az információ keresés intenzitását gyakran a fogyasztó érintettsége határozza meg. „A vásárlási döntésben kifejezetten érintett vásárló számára (legyen szó bármilyen termékről) a folyamat valamennyi lépése fontossággal bír, így intenzív információkeresésben van, a megszerzett információkat feldolgozza és így dönt, valamint a megszerzett tudást, tapasztalatot tárolja is.” Magas érintettség esetén fontos a meggyőzés, elkötelezés adott márka iránt, a részletes információközlés, tárgyszerü érvek. Alacsony érintettség esetén inkább a kapcsolatfelvétel, a rövid információátadás, vonzó érzelmi hatás, valamint az állandó jelenlét a fontos (TÖRŐCSIK, 2007, 176-177. o.).

Az érintettség esetén fontos annak forrása is, melyet Törőcsik négy kategóriába sorolt. Személyes érintettség lényege, hogy a fogyasztó személyes vágyait kívánja kielégíteni, ezek erősségétől függ az érintettség intenzitása is. A termék vonzereje elsősorban környezeti impulzusok alapján hat, a marketingkommunikáció alakítja ki. Szituációfüggő érintettség gyakori kategória, jelentős számban vezet impulzusvásárláshoz. A médiaérintettséget az adott médium hatásfoka váltja ki (TÖRŐ́CSIK, 2007, 178. o.).

A fogyasztó információszerzését és az in- 
formáció fogyasztói attitűdre gyakorolt hatását tehát számos tényező befolyásolja, emellett egyénenként is eltérő lehet, hiszen a személyes tulajdonságok egyértelmüen hatást gyakorolnak az információ-feldolgozás folyamatára.
Az alábbi modellben a fenti szakirodalmak felhasználásával az információ feldolgozására ható fóbb tényezők összefoglalása látható (1. ábra).

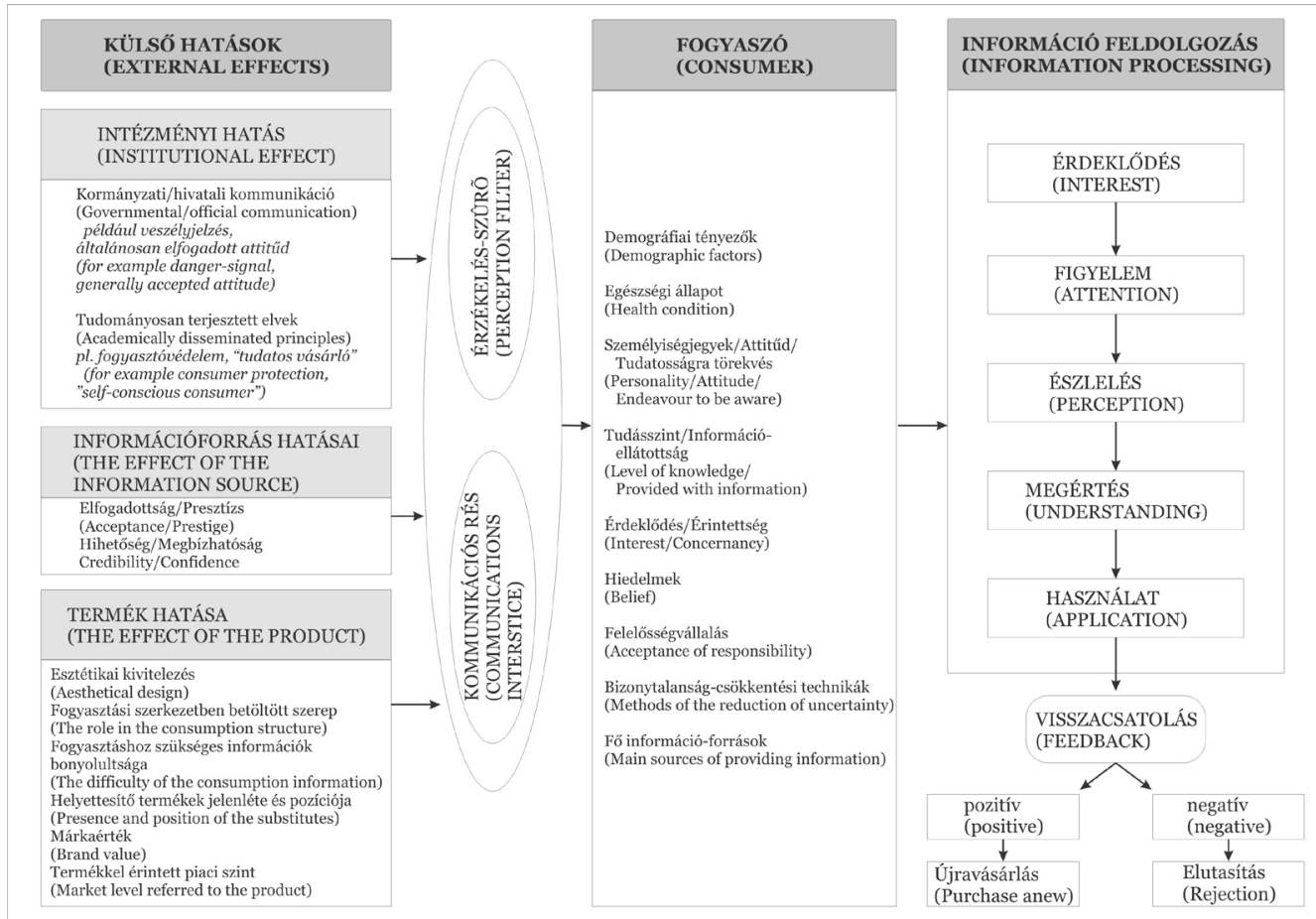

1. ÁBRA

A fogyasztó információkezelésére ható tényezők

FIG. 1

\section{(The Influential Factors on the Information Processing of the Consumer)}

Forrás (Source): a cikkben szereplő szakirodalmak alapján saját szerkesztés (Edited based on the literature of this paper)

\section{AZ INFORMÁCIÓKEZELÉS GYAKORLATA - The Practice OF THE INFORMATION PROCESSING}

Számos kutatás vizsgálta, hogy a vásárlók milyen gyakran olvassák el az élelmiszereken elhelyezett tájékoztató címkét. Egy amerikai kutatás szerint a válaszadók 67\%-a rendszeresen vagy legalább néha elolvassa a termékinformációkat vásárlás előtt. A leginkább keresett információ a tartalmazott kalória mértéke (HAWLEY et al., 2012, 430-431. o.).

Egy másik amerikai kutatás közel 3000 válaszadó segítségével vizsgálta a címkék fo- gyasztókra gyakorolt hatását, valamint vizsgálta a címkehasználat demográfiai jellemzőkkel vett összefüggéseit. A tanulmány szerint a vizsgált személyek 80\%-a olvassa el rendszeresen a termékinformációkat (CHEN et al, 2011).

Liu és szerzőtársai 2015-ben publikált tanulmányában nagymintás regressziós modellek segítségével vizsgálta bizonyos változók (például lakóhely, nem, kor, oktatási szint, diéta, ismeretszint és a BMI) és a termékcímke-használat közötti összefüggést. Bizonyították, hogy a résztvevők nagyobb arányban értik meg a termékcímke információit, ha előzetes ismeretszintjük magasabb, valamint gyakrabban használják a termékcímke-információkat 
a vásárlás során, ha alacsonyabb a BMI-indexük. A szerzők modelljükben különbséget tesznek objektív és szubjektív megértés között. Az objektív megértés az, amikor a fogyasztó úgy értelmezik az információ-kibocsátó által küldött információt, ahogy a küldő értelmezte. A szubjektív megértés (felismerés) a fogyasztó érzéseit, értékeléseit, hitét tartalmazza az adott információval kapcsolatban. Eszerint a vizsgált kínai fogyasztók esetében a szubjektív megértés szignifikáns pozitív kapcsolatban áll a termékcímke-használattal, míg a objektív információk esetében ilyen összefüggést nem tapasztaltak.

Tehát a szubjektív, azaz az egyes fogyasztók információfeldolgozási folyamatán és egyéni sajátosságain alapuló megértési folyamatnak van mérhető szerepe a címkehasználati szokásokban. A szubjektív megértésre elsősorban az életkor, a termékcímkék ismeretének foka, a szubjektív és objektív táplálkozási tudás hatott elsősorban, míg az objektív megértést inkább az életkor, az iskolázottság, a BMI, a diéta határozta meg a termékcímkék ismeretének foka és a szubjektív és objektív táplálkozási tudás mellett. A kor fordítottan arányos a címkehasználattal, a fiatalabb vásárlók jobban megértik az információkat a terméken. Ugyanakkor felmérésük szerint az iskolázottság és a diétázó állapot nem magyarázza a címkehasználatot. Ennek az is lehet az oka, hogy a magasabban képzett fogyasztók nem hisznek a címkén szereplő információkban. A BMI szignifikánsan negatív hatást gyakorol a címkehasználatra. Ennek az lehet az oka, hogy a magasabb BMI-vel rendelkező fogyasztók kevésbé hiszik el, hogy a terméken szereplő információk számukra hasznosak, használhatók. Ebből következően a normál vagy alacsonyabb testsúlyú fogyasztók nagyobb eséllyel használják a termékinformációkat élelmiszer-vásárlási döntéseiknél (LIU, HOEFKENS és VERBEKE, 2015). Érdekes ellentmondás, hogy a magasabb végzettséggel/ tudással rendelkező fogyasztók gyakrabban keresik az információkat, ugyanakkor azok állításait kevésbé hiszik el. Számukra a hitelesség biztosítása alapvető fontosságú.

Grunert szerint a termékcímke nagyobb szerepet kap azon termékek esetében, amelyek nem márkázottak, hiszen márkás termékeknél a fogyasztó termékkel, márkával kapcsolatos korábbi tapasztalatai vezérlik a döntést. Nem márkázott termékek esetén nagyobb az információkeresési igény, vagy hajlandóság, így a címke nagyobb mértékben befolyásolhatja a fogyasztó választását. Ugyanakkor azt is megállapította, hogy a minőségi jelzők a címként kevésbé befolyásolják a vásárlót. Ennek oka az ismeretek, vagy tudatosság hiánya, illetve az, hogy félreértik vagy saját észlelésük folyamatában túlértékelik azokat (GRUNERT, 2002). A minőségi jelzők akkor müködnek, ha kevés van belőlük, egyértelmüen azonosítják a fogyasztó számára fontos értéket és kellően hihető állítást takar. Az erős márka ugyanakkor fokozza a hiteles tájékoztatás jelentőségét, vagy tompítja a negatív hatásokat. Ez nem feltétlenül az észlelésnél, inkább az információfeldolgozás későbbi szakaszában megy végbe, vagy a vásárlást követő utólagos fogyasztói értékelésben kap szerepet.

Az ír fogyasztók körében végzett vizsgálat célja az EU 1924/2006-os szabályozásának vizsgálata volt. Ennek kapcsán a 400 értékelhető kérdőív segítésével értékelték a fogyasztók információkeresési, megértési, használati folyamatát. A kutatásban, hasonlóan Hawleyhez, a fogyasztók 67\%-a olvasta el a termékcímkéket (HAWLEY et al., 2012). A nemek közti különbséget vizsgálva a nők gyakrabban olvassák el az információkat. A termékösszetevőkre vonatkozó állításokat a megkérdezettek magas, 82-91\%-os részaránya értette meg, a hit a hölgyekben volt szignifikánsan erősebb számos termék, így például a probiotikus joghurt hatásában (LYNAM, McEWITT és GIBNEY, 2011).

Grunert és társai a kérdőíves in-store megkérdezés mellett megfigyelést is végeztek. A megfigyeltek $65,6 \%$-a nézte meg a termék front oldalát, további 11,6\%-uk a terméket máshol és 31,8\%-uk nem nézte meg a terméket részletesen. A kérdőíves felmérésben vizsgálták, hogy általában mennyire nézik meg a fogyasztók az élelmiszercímkéket, itt 47,4\% válaszolta, hogy mindig, vagy rendszeresen. Érdekesség, hogy azok közül, akik a megfigyelt vásárlásnál nem olvasták el a címkét, 38\%-uk állítja, hogy mindig, vagy rendszeresen figyelnek rá, ha ezt a terméket vásárolják. A leggyakrabban vizsgált információk voltak sorrendben a zsír, cukor, kalóriák és a só (GRUNERT, WILLS és FERNÁNDEZ-CELEMIN, 2010). A fogyasztók 
nyilvánvalóan azokat az információkat keresik, amelyek az egészségi állapotuk, tervezett diétájuk miatt fontosak, ugyanakkor megértik a címkén szereplő tájékoztatást, illetve ez alapján össze tudják hasonlítani a helyettesítő termékeket. E tekintetben fontos az egységes szabályozás, ugyanakkor nem szabad figyelmen kívül hagyni a marketing célokat sem, azaz, hogy a tájékoztatás legyen rövid, érthető, megjegyezhető.

\section{KöVETKEZTETÉSEK ÉS JAVASLATOK - CONCLUSIONS AND SUGGESTIONS}

A fogyasztó vásárlás során tanúsított magatartását, a fogyasztási szerkezetről és a termékek közötti választásról hozott döntést számtalan külső és belső tényező befolyásolja. A fogyasztót a vásárlást megelőzően és a folyamat közben is sok információ éri. Fontos szerepe van az információk körét és jellegét meghatározó törvényi előírásoknak, az élelmiszerbiztonsággal és táplálkozástudománnyal foglalkozó kutatóintézetek, hivatalok tájékoztató tevékenységének és nem utolsó sorban a gyártóknak és forgalmazóknak is abban, hogy a vásárló megbízható, hiteles, érthető információkat kapjon a tervezett termékvásárlásához. A fogyasztók meglévő tudásszintje, iskolázottsága meghatározza az információkeresés intenzitását, az információk feldolgozásának folyamatát és alaposságát, valamint a vásárláskori attitűdöt. Ahogy a vásárlási magatartásban alapvetően, úgy az információkeresésben is különbség van a különböző nemek képviselői között. A nők fogékonyabbak az információk keresésére és befogadására, amely egyébként részben a nagyobb vásárlási gyakorisággal is magyarázható.

Különbség tapasztalható a fogyasztók földrajzi hovatartozásában is, az európai fogyasztók címkeolvasási hajlandósága kisebb, mint néhány ázsiai országban. A földrajzi tényezők mellett fontos például a kor, idősebb fogyasztók tudatosabbak, ez részben összefügg azzal is, hogy az alapbetegség megléte (fiatalabbaknál az életmódbetegségek is) motiválják a vásárlót a tudatosságra.

A fogyasztók között jelentős különbség mu- tatkozhat meg az információfeldolgozás folyamatában, a tudatos vagy tudat alatti megértés jellegében, az egyes szituációkkal összefüggő attitűd tekintetében is. Ezeket a differenciákat korrigálják az előzetes hiedelmek, az érintettség és a fogyasztó által felvállalt felelősség is.

$\mathrm{Az}$ információkezelésben fontos szerepet játszik az információ-kibocsátó presztízse, hihetősége. Fontos azonban megjegyezni, hogy az információforrás és a fogyasztó között egy ún. „érzékelés szűrő” múködik, amely a tudományos állítás, vagy kommunikált információ reális és a fogyasztó által érzékelt tudattartalma között eltéréseket okoz. Hasonló eltérést eredményezhet az ún. „kommunikációs rés”, amely a tudományos és marketing információk közötti képez differenciát. Ezek áthidalása a fogyasztó hiteles meggyőzésének kulcsa és minden érintett feladata kell, hogy legyen.

Fontos feladat az élelmiszeripari kommunikáció jövőjét tekintve, hogy a szereplők megtalálják azokat az információforrásokat, amelyek megfelelnek az elérni kívánt piaci szintnek, ott olyan egyszerüen leírt, bizonyított, hihető és meggyőző információkat közöljenek, amely hatással lesz a fogyasztó - utólag is igazolt - optimális döntésére és kedvező irányba befolyásolja az élettani állapotát, egyben elégedettséget vált ki hosszú távon.

\section{7. ÖSSZEFOGLALÁS - SUMMARY}

A fenti szakirodalmi áttekintés rámutatott arra, hogy fogyasztók a vásárlást megelőzően, annak folyamán és azt követően is számtalan információval találkoznak, melyek befolyásolják magatartásukat. Az élelmiszeripar és -kereskedelem, a kormányzat szereplőinek közös feladata a fogyasztók korrekt, érthető, informatív támogatása, amellyel a vásárlók a saját adottságaiknak legmegfelelőbb termékeket tudják kiválasztani és fogyasztani. Az alkalmazott termékszerkezet visszahat az egészségi állapotukra és körforgásszerüen befolyásolja további magatartásukat.

A fogyasztók vizsgálata sok területet érint. A demográfiai és földrajzi tényezők mellett fontos a személyiségjegyek minél behatóbb tanulmányozása annak érdekében, hogy a célpiac információkkal szembeni reakcióját megérthessük. A könnyebben kategorizálható tulaj- 
donságok, mint például a végzettség, foglalkozás mellett fontos a tudásszint és az esetleges hiedelmek meghatározása, amely alapvetően befolyásolja az információkeresés és -feldolgozás folyamatát. A használt információforrások szegmentumonként különböznek, így ezt mindig termékspecifikusan és célcsoportonként kell meghatározni.

A megfelelő információk biztosításához a termékcímke fontos eszközt jelent, melyet egyrészt törvényi előírások határoznak meg, másrészt a marketing funkcióknak is érvényre kell jutniuk ezek tervezésekor. Az egyszerúen megfogalmazott, érthető, hihető információk pozitívan hatnak a fogyasztóra, míg a bonyolult, érthetetlen, vagy túl sok információ a vásárlás elutasítását vonhatja maga után.

\section{IRODALOMJEGYZÉK - REFERENCES}

Chen, X. - Jahns, L. - Gittelsohn, J. Wang, Y.: Who is Missing the Message? Targeting Strategies to Increase Food Label Use Among US Adults. In: Public Health Nutrition. 2011. 15 (5) 760-772.

Grunert, G. K.: Current Issues in the Understanding of Consumer Food Choice. In: Trends in Food Science \& Technology. 2002. 13 275-285.

Grunert, G. K. - Wills J. M.: A Review of European Research on Consumer Response to Nutrition Information on Food Labels. In: Journal of Public Health. 2007. 15 385-399.

Grunert, G. K. - Wills, J. M. - FernándezCelemin, L.: Nutrition Knowledge, and Use and Understanding of Nutrition Information on Food Labels Among Consumers in the UK In: Appetite. 2010. 55 77-189.

Hawley, K. L. - Roberto, C. A. - Bragg, M. A. - Liu, P. J. - Schwartz, M. B. - Brownell, K. D.: The science on frontof-package food labels. In: Public Health Nutrition 2012. 16 (3), 430-439.

Lehota J.: Élelmiszergazdasági marketing. Műszaki Könyvkiadó, Budapest, 2001.
Lehota J.: Az élelmiszerfogyasztással kapcsolatos észlelt kockázatok és kockázatkezelési alternatívák. In: Élelmiszer, Táplálkozás és Marketing 2006. 3 (1) 13-18.

Liu, R. - Hoefkens, C. - Verbeke, W.: Chinese Consumers' Understanding and Use of a Food Nutrition Label and Their Determinant. In: Food Quality and Preference. 2015. 41 103-111.

Lynam, A-M. - McKevitt, A. - Gibney, M. J.: Irish Consumers' Use and Perception of Nutrition and Health Claims In: Public Health Nutrition. 201114 (12) 2213-2219.

Szakály Z.: Táplálkozásmarketing. Mezőgazda Kiadó, Budapest, 2011.

Törőcsik M.: Vásárlói magatartás. Akadémiai Kiadó, Budapest, 2007.

Verbeke, W.: Consumer Acceptance of Functional Foods: Socio-demographic, Cognitive and Attitudinal Determinants. In: Food Qual Prefer. 2005. 16 45-57.

Verbeke, W.: Az élelmiszer kockázatokra adott fogyasztói reakciók és a kommunikáció. In: Élelmiszervizsgálat Közlemények. 2007. 53 (1) 26-36.

Verbeke, W.: Impact of communication on consumers' food choices Plenary Lecture. In: Proceedings of the Nutrition Society. 2008. 67 281-288.

178/2002/EK rendelet az élelmiszerjog általános elveiről és követelményeiről, az Európai Élelmiszerbiztonsági Hatóság létrehozásáról és az élelmiszerbiztonságra vonatkozó eljárások megállapításá ról Európai Uniós joganyag http://eur-lex. europa.eu/LexUriServ/LexUriServ.do? uri=CONSLEG:2002R0178:20090807 :HU:PDF (Letöltés dátuma: 2016. febr. 24.)

1995. évi XC. törvény az élelmiszerekről és végrehajtási rendelete: 1/1996. (I. 9.) FMNM-IKM rendelet és módosítása a 2001. évi LIV. törvény http://mkogy.jogtar. hu $/$ ? page $=$ show \&docid $=99500090 . \mathrm{TV}$ (Letöltés dátuma: 2016. febr. 24.) 
Magyar Élelmiszerkönyv (Codex Alimentarius Hungaricus) http:// www.omgk.hu/magyarelelmiszerk.htm (Letöltés dátuma: 2016. febr. 24.)

2000/13/EK Európai Parlament és a Tanács irányelve az élelmiszerek címkézésére, kiszerelésére és reklámozására vonatkozó tagállami jogszabályok közelítéséről http://eur-lex. europa.eu/LexUriServ/LexUriServ.do ?uri=CONSLEG:2000Lo013:20110120 :HU:PDF (Letöltés dátuma: 2016. febr. 26.)

2003. évi LXXXII. törvény az élelmiszerekről http://mkogy.jogtar. $\mathrm{hu} /$ ?page $=$ show\&docid $=$ a0300082.TV (Letöltés dátuma: 2016. febr. 24.)

1169/2011/EU Európai Parlament és a Tanács rendelete (2011. okt. 25.) a fogyasztók élelmiszerekkel kapcsolatos tájékoztatásáról http://eur-lex.europa. eu / LexUris erv / LexUriServ.do? uri=OJ:L:2011:304:0018:0063:HU:PDF (Letöltés dátuma: 2016. febr. 26.)

19/2004. (II. 26.) FVM-ESzCsM-GKM együttes rendelet az élelmiszerek jelöléséről http://net.jogtar.hu/jr/ gen/hjegy_doc.cgi?docid=A0400019. FVM\&celpara=\#xcelparam (Letöltés dátuma: 2016. febr. 26.), valamint Magyar Közlöny 2004. évi 20. szám.
36/2014. (XII. 17.) FM rendelet az élelmiszerekkel kapcsolatos tájékoztatásról http://njt.hu/cgi_bin/njt_ doc.cgi?docid=173097.286272 (Letöltés dátuma: 2016. febr. 26.)

13/2008. (VIII. 8.) NFGM-FVM együttes rendelet az előrecsomagolt termékek névleges mennyiségére vonatkozó szabályok megállapításáról és azok ellenőrzési módszereiről http: / / net.jogtar.hu/jr/gen / hjegy_doc.cgi?docid=Ao800013. NFG\&celpara $=\#$ xcelparam (Letöltés dátuma: 2016. febr. 26.)

74/2012. (VII. 25.) VM rendelet egyes önkéntes megkülönböztető megjelölések élelmiszereken történő használatáról http://net.jogtar.hu/jr/ gen/hjegy_doc.cgi?docid=A1200074. VM\&celpara $=\#$ xcelparam

(Letöltés dátuma: 2016. febr. 26.)

White Paper On Food Safety http:// ec.europa.eu/dgs/health_food-safety/ library/pub/pubo6_en.pdf (Letöltés dátuma: 2016. febr. 29.)

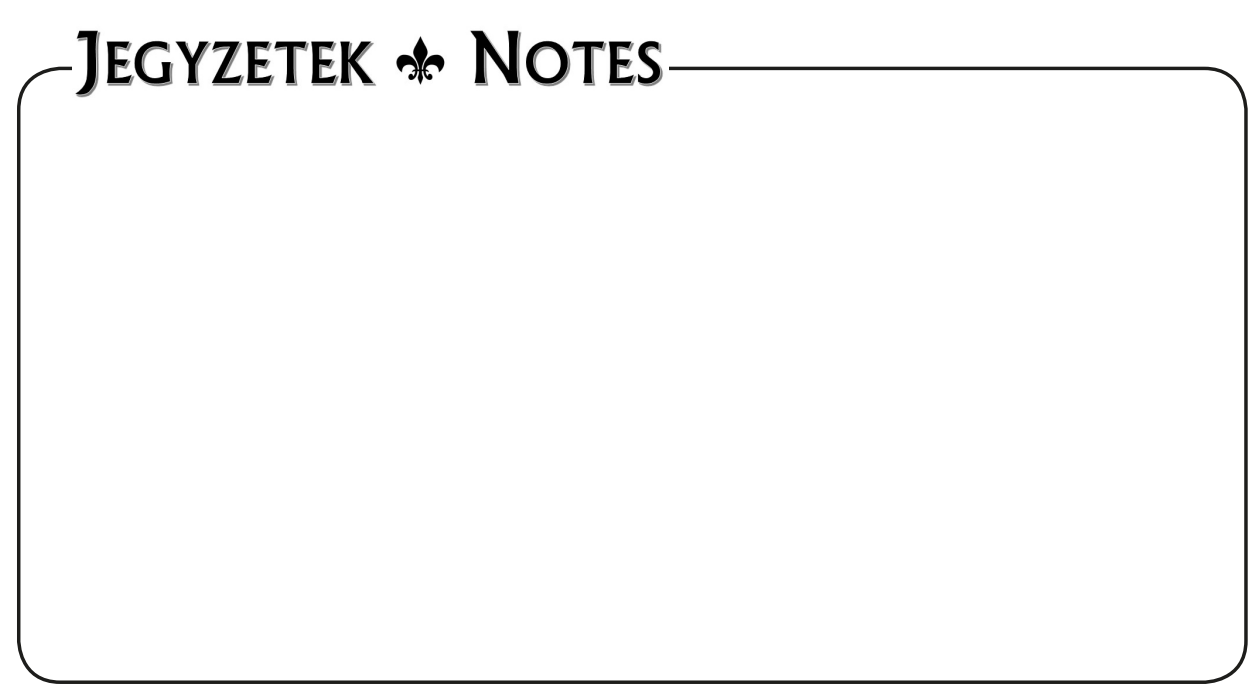

